\title{
Agronomic performance of arugula/nira intercropping in different cultivation arrangements
}

\author{
Marcelo de A Guimarães ${ }^{1} \mathbb{D}$; Benedito P Lima Neto ${ }^{1} \mathbb{D}$; Hozano de S Lemos Neto ${ }^{2} \mathbb{D}$; Ana RA de A Hendges ${ }^{3} \mathbb{D}$; \\ Caris dos $\mathrm{S}$ Viana ${ }^{1} \mathbb{D}$; Janiquelle da $\mathrm{S}$ Rabelo ${ }^{1} \mathbb{D}$
}

ŁUniversidade Federal do Ceará (UFC), Fortaleza-CE, Brasil; mguimara@ufc.br; benepneto@gmail.com; carisviana@hotmail.com; rabelojs@ hotmail.com; ${ }^{2}$ Universidade Federal Rural do Semi-Árido (UFERSA), Mossoró-RN, Brasil; hozanoneto@hotmail.com (corresponding author); ${ }^{3}$ Instituto Federal de Educação, Ciência e Tecnologia do Maranhão (IFMA), São Raimundo das Mangabeiras-MA, Brasil; ana. alves@ifma.edu.br

\begin{abstract}
Spatial planning of cultivation arrangements is essential to ensure the superiority of intercropping when compared with monocrop. Thus, the aim of this study was to evaluate the agronomic performance of arugula/nira intercropping in different cultivation arrangements. The experiment was carried out in a randomized block design, in a split plot scheme, the plots represented the cultivation arrangements and the subplots the production cycles (winter and spring). The arrangements were $\mathrm{T}_{1}=$ arugula monoculture; $\mathrm{T}_{2}=$ two rows of arugula alternating with three rows of nira $(2 \mathrm{R}: 3 \mathrm{~N}) ; \mathrm{T}_{3}=$ two rows of arugula alternating with two rows of nira $(2 \mathrm{R}: 2 \mathrm{~N}) ; \mathrm{T}_{4}=$ two rows of arugula alternating with one row of nira $(2 \mathrm{R}: 1 \mathrm{~N}) ; \mathrm{T}_{5}=$ nira monoculture. Productive traits and agronomic performance indexes of the intercropping systems were evaluated. Single arugula cultivation and $2 \mathrm{R}: 1 \mathrm{~N}$ intercropping achieved similar productivity, $2 \mathrm{R}: 1 \mathrm{~N}$ intercropping showed the highest productive efficiency, with land-use efficiency of $1.16 \%$, though arugula showed a relative contribution of $84.3 \%$ in production yield of the system. We concluded that $2 \mathrm{R}: 1 \mathrm{~N}$ intercropping can be used to optimize the use of productive inputs in arugula cultivation.
\end{abstract}

Keywords: Eruca sativa, Allium tuberosum, efficient use of land, productivity.

\section{RESUMO}

Desempenho agronômico do consórcio rúcula e nirá em diferentes arranjos de cultivo

O planejamento espacial dos arranjos de cultivo é fundamental para garantir a superioridade do consórcio em relação ao monocultivo. Assim, objetivou-se avaliar o desempenho agronômico do consórcio rúcula e nirá em diferentes arranjos de cultivo. O experimento foi conduzido no delineamento em blocos casualizados, em esquema de parcela subdividida, com as parcelas sendo os arranjos de cultivo e as subparcelas os ciclos de produção (inverno e primavera). Os arranjos foram $\mathrm{T}_{1}=$ monocultivo de rúcula; $\mathrm{T}_{2}=$ duas linhas de rúcula alternadas com três de nirá ( $2 \mathrm{R}: 3 \mathrm{~N}) ; \mathrm{T}_{3}=$ duas linhas de rúcula alternadas com duas de nirá (2R:2N); $\mathrm{T}_{4}=$ duas linhas de rúcula alternadas com uma de nirá ( $2 \mathrm{R}: 1 \mathrm{~N}) ; \mathrm{T}_{5}=$ monocultivo de nirá. Foram avaliadas as características produtivas e os índices de desempenho agronômico dos consórcios. A rúcula solteira e o cultivo consorciado $2 \mathrm{R}: 1 \mathrm{~N}$ alcançaram produtividade semelhante, porém o cultivo consorciado $2 \mathrm{R}: 1 \mathrm{~N}$ foi o que apresentou maior eficiência produtiva, com uso eficiente da terra (UET) de 1,16\%, tendo a rúcula uma contribuição relativa de $84,3 \%$ no rendimento produtivo do sistema. O cultivo consorciado $2 \mathrm{R}: 1 \mathrm{~N}$ pode ser utilizado para a maior otimização no uso dos insumos produtivos em cultivo de rúcula.

Palavras-chave: Eruca sativa, Allium tuberosum, uso eficiente da terra, produtividade.

Received on March 23, 2020; accepted on July 1, 2020

$I^{\mathrm{n}}$ ntercropping is a technique in which two or more species are grown simultaneously in the same area, during, at least, part of the life cycle of each crop (Silva et al., 2011; Hendges et al., 2017). Intercropping increases productivity and profits per area, making production systems more sustainable, since the grown area and other available resources (soil, water, light and nutrients) are more appropriately used. This agriculture method also reduces economic risks due to the possibility of crop diversification
(Lira \& Edilson, 2013; Damasceno et al., 2016; Hendges et al., 2017). However, in order to maximize the use of the resources in intercropping, the crops must be adjusted in a way to maintain the greatest complementarity between each other.

Some studies on intercropping have reported that some species show high biological and productive efficiency, such as arugula and chicory (Cichorium intybus) (Cecilio Filho et al., 2008); arugula and carrot (Daucus carota)
(Lima et al., 2013) and kale and herbs (Hendges et al., 2017).

Arugula (Eruca sativa) is a shortcycle leafy vegetable, widely used in Brazilian cuisine. Despite little technical information about its cultivation, arugula has been widely grown throughout all Brazilian regions (Oliveira et al., 2015). In Brazil, this is one of the main leafy vegetables and, despite being traditionally grown in monocrop, it has excellent potential use in intercropping (Nunes et al., 2013). 
"Nira" (Allium tuberosum), although not being popular in Brazil, is one of the main condiment crops in Asia. This species shows high potential to be used in intercropping with vegetables: it can increase productivity and also contributes to reducing pest infestation (Souza \& Macedo, 2007; Porto, 2008).

Nevertheless, it is necessary to establish an appropriate growing arrangement in order to obtain high production and intercropping efficiency (Oliveira et al., 2015). It is essential that plant size, root system and canopy density be studied previously in order to identify if the interaction is possible (Sugasti et al., 2013). Thus, the aim of this study was to evaluate agronomic performance of arugula/nira intercropping in different cultivation arrangements.

\section{MATERIAL AND METHODS}

The experiment was carried out from July to November 2017, in the experimental area at Horta Didática, Universidade Federal do Ceará (UFC), Fortaleza-CE (3⒋'17'S, 38³4'29"W, $21 \mathrm{~m}$ altitude). The local climate is 'As', dry summer tropical climate, average annual temperature is $26^{\circ} \mathrm{C}$ and $1,450 \mathrm{~mm}$ rainfall (Alvares et al., 2014). During the experiment (July 17 to November 18), the average temperature was $28^{\circ} \mathrm{C}$, minimum $23^{\circ} \mathrm{C}$ and maximum $32^{\circ} \mathrm{C}$, relative humidity $66 \%$ and accumulated rainfall $79.5 \mathrm{~mm}$.

The soil in the experimental area was sampled (0-20-cm-deep layer). After preparation, and incorporation of organic compost, the soil showed the following chemical characteristics: $\mathrm{pH}$ $\left(\mathrm{H}_{2} \mathrm{O}\right)=7.2 ; \mathrm{P}=344.3 \mathrm{mg} \mathrm{dm}^{-3}$ and $\mathrm{K}^{+}=230.0 \mathrm{mg} \mathrm{dm}^{-3} ; \mathrm{Ca}^{2+}=10.4 \mathrm{cmolc}$ $\mathrm{dm}^{-3} ; \mathrm{Mg}^{2+}=6.4 \mathrm{cmolc} \mathrm{dm}^{-3} ; \mathrm{H}+\mathrm{Al}$ $=0.99 \mathrm{cmolc} \mathrm{dm}^{-3} ; \mathrm{SB}=17.4 \mathrm{cmolc}$ $\mathrm{dm}^{-3} ; \mathrm{CTC}=18.4 \mathrm{cmolc} \mathrm{dm}^{-3}$ and $\mathrm{V}=$ $95 \%$. Mehlich ${ }^{1}$ method was used for extraction.

The experimental design was randomized blocks, arranged in split plot scheme subdivided in time $(5 \times 2)$, considering some plots as cultivation arrangements and subplots the two production cycles (winter and spring), with four blocks. The arrangements (treatments) consisted of single cultivation and arugula/nira intercropping cultivation described as: $\mathrm{T}_{1}=$ arugula monoculture; $\mathrm{T}_{2}=$ two rows of arugula alternating with three rows of nira $(2 \mathrm{R}: 3 \mathrm{~N}) ; \mathrm{T}_{3}=$ two rows of arugula alternating with two rows of nira $(2 \mathrm{R}: 2 \mathrm{~N}) ; \mathrm{T}_{4}=$ two rows of arugula alternating with one row of nira (2R:1N); $\mathrm{T}_{5}=$ nira monoculture.

The experimental plot consisted of an area covering $2.0 \mathrm{~m}^{2}(1.0 \times 2.0 \mathrm{~m})$. Spacings were $0.2 \times 0.2 \mathrm{~m}$ for arugula and $0.1 \times 0.1 \mathrm{~m}$ for nira. In the intercropping systems, nira plants were spaced 0.20 $\mathrm{m}$ from the arugula cultivation rows. The useful area of the plot consisted of four central rows of arugula and two central rows of nira, measuring $1.0 \mathrm{~m}^{2}$. The authors evaluated 20 plants per crop per replicate.

Arugula was sown in 162-cell trays, filled with substrate based on organic compost and carnauba leaf, at 4:1 ratio, using cultivar 'Cultivada' (Topseed Garden $\left.{ }^{\circledR}\right)$. At 20 days after sowing (DAS), seedlings were transplanted into seedbeds. Soil preparation consisted of soil tillage and addition of $12 \mathrm{~kg}$ $\mathrm{m}^{-2}$ of organic compost composed of cattle manure, vegetable remains prepared in the didactic vegetable garden. The organic compost used in fertilization showed the following chemical characteristics: $\mathrm{N}=5935 \mathrm{~g}$ $\mathrm{dm}^{-3} ; \mathrm{P}=368.7 \mathrm{mg} \mathrm{dm}^{-3} ; \mathrm{K}^{+}=2300 \mathrm{mg}$ $\mathrm{dm}^{-3} ; \mathrm{Ca}^{2+}=10.9 \mathrm{cmolc} \mathrm{dm}^{-3} ; \mathrm{Mg}^{2+}=$ $9.4 \mathrm{cmolc} \mathrm{dm}^{-3} ; \mathrm{Zn}=98 \mathrm{mg} \mathrm{dm}^{-3} ; \mathrm{Fe}$ $=21.1 \mathrm{mg} \mathrm{dm}^{-3} ; \mathrm{Mn}=67.7 \mathrm{mg} \mathrm{dm}^{-3}$; $\mathrm{Cu}=0.7 \mathrm{mg} \mathrm{dm}^{-3} ; \mathrm{B}=1.6 \mathrm{mg} \mathrm{dm}^{-3}$. Neither mineral fertilization nor liming was necessary.

Nira was vegetatively propagated using tillers of plants which were already produced in the didactic vegetable garden of UFC. Tillers were separated, roots were partially eliminated and shoots were cut (leaving approximately $3-\mathrm{cm}$ leaves). Then tillers were transplanted. Two cultivation cycles for arugula and one cultivation cycle for nira were carried out.

Irrigation was performed daily, through micro-sprinkler irrigation with operating pressure of 110 mca (meter of water column) in the morning and afternoon, in order to keep appropriate soil moisture. Weeds were controlled manually (hoeing or hand-picking), as required. Top-dressing fertilizations were performed by applying $5 \mathrm{~kg}$ $\mathrm{m}^{-2}$ of organic compost, followed by scarification, at seven and 21 days after transplanting (DAT) of arugula seedlings. Pests were visually monitored at weekly intervals.

Arugula was harvested at 30 DAT in the first and second cycle, and the following agronomic parameters were evaluated: plant height $(\mathrm{PH}, \mathrm{cm})$, number of leaves (NL), leaf area (LA, $\mathrm{cm}^{2}$ ), marketable fresh mass (MFM, g), marketable dry mass (MDM, g) and productivity (PROD, $\mathrm{t} \mathrm{ha}^{-1}$ ). The marketable part was characterized by leaves without apparent damages and leaves showing apparent damages were classified as non-marketable. Nira was harvested at 90 days after planting (DAP), and plant height (PH, $\mathrm{cm}$ ), average number of tillers per plant (NTPP), number of leaves (NL), shoot fresh mass (SFM, g), shoot dry mass (SDM, g) and productivity (PROD, $\mathrm{t}$ $\mathrm{ha}^{-1}$ ) were evaluated.

Height was determined with the aid of a graduated scale. For arugula plant, the height was measured from the stem until the leaf priomordia, for nira, from the soil to the end of the leaf. Masses were quantified using a digital scale with centesimal precision. In order to quantify dry mass, the fresh vegetables were placed in an oven with forced air circulation at $65^{\circ} \mathrm{C}$, until constant mass. Leaf area was measured using a benchtop model LI-3100C, LI-COR.

Using the productivity parameters of the crops, we calculated the following indexes: land use efficiency index (LUE), relative contribution of arugula to LUE (RCC), area time equivalent ratio (ATR) and system productivity index (SPI).

The land use efficiency index (LUE) was calculated using the formula proposed by Willey (1979):

$$
L U E=\frac{Y a b}{Y a a}+\frac{Y b a}{Y b b}
$$

where, Yab is the production of "a" crop intercropped with "b" crop, Yba is the production of "b" crop intercropped with "a" crop, Yaa is the production 
of "a" monoculture and Ybb is the production of "b" monoculture.

RCC was calculated using the formula proposed by Souza \& Macedo (2007):

$$
R C C=\frac{I \times 100}{U E T}
$$

where, I is the individual relative productivity; LUE is land-use efficiency index.

SPI standardizes the yield of the secondary crop in relation to the main crop, being calculated according to Odo's methodology (1991):

$$
S P I=\left\{\left(\frac{Y a a}{Y b b}\right) \times Y b a\right\}+Y a b
$$

in which: Yaa is the yield of "a" in monoculture, Ybb is the yield of " $b$ " in monoculture; Yab is the yield of " $a$ " crop intercropped; Yba is the yield of "b" crop intercropped.

Data were submitted to Shapiro Wilk's test (normality test) and, then, the authors performed ANOVA F test and averages were compared through Tukey test at 5\% significance, using Sisvar software (Ferreira, 2011).

\section{RESULTS AND DISCUSSION}

Based on ANOVA F test, the authors verified interaction effect $(\mathrm{p} \leq 0,01)$ between cultivation arrangements and production cycles for number of leaves (NL), leaf area (LA), marketable fresh and dry mass (MFM and MDM) and productivity. Plant height showed significant difference only between the production cycles.

For NL, the authors observed that 2R:3N and 2R:1N arrangements showed the greatest number of emissions in the first cycle. In the second cycle, the single arugula and 2R:1N arrangement showed the greatest NL (Table 1). Leaf area in the first cycle of arugula was higher in intercropping systems, whereas in the second cycle, the plants from single cultivation and intercropped with an alternated row of nira showed the highest LAs.

For marketable fresh and dry mass, in the first cycle, arugula plants from intercropping treatments were always superior to the ones produced in the single cultivation (Table 2). In the second cycle, single arugula and 2R:1N intercropping was superior to the other treatments.

This differentiated behavior in cultivation systems in the two production cycles can be related to the fact that in the second cycle of arugula, nira plants showed to be higher, which can have caused greater interference on the arugula, mainly when more rows of nira, between rows of arugula, were used. Thus, an interspecific competition for space between these crops probably occurred in the second cycle.

In general, interspecific competition can be justified by greater plant density which leads to increased competition for growth factors such as solar radiation, water and nutrients limiting leaf expansion (Zanine \& Santos, 2004). Besides that, canopy formation speed and leaf architecture of the intercropping can also modify complementarity between crops when associated, according to observed in lettuce/ cucumber intercropping, in which the

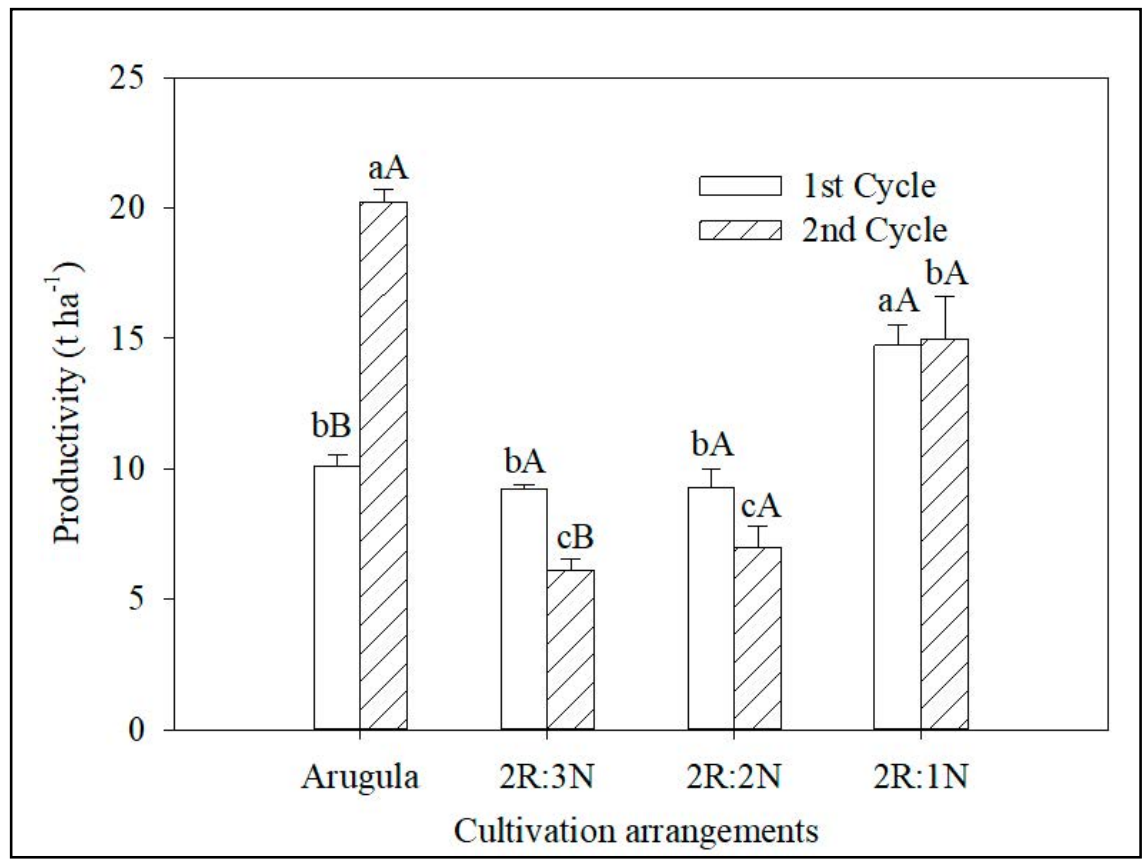

Figure 1. Productivity of arugula plants in different cultivation arrangements with nira and production cycle (winter and spring). Averages followed by the same lowercase letter between cultivation arrangements and uppercase letters between production cycles do not differ statistically from each other, by Tukey test, $\mathrm{p} \leq 0.05\}$. Fortaleza, UFC, 2017.

Table 1. Number of leaves (NL) and leaf area (LA) of arugula plants in different cultivation

\begin{tabular}{|c|c|c|c|c|}
\hline \multirow{2}{*}{$\begin{array}{l}\text { Cultivation } \\
\text { system }\end{array}$} & \multicolumn{2}{|c|}{ NL } & \multicolumn{2}{|c|}{$\operatorname{LA}\left(\mathrm{cm}^{2}\right)$} \\
\hline & $1^{\text {st }}$ cycle & $2^{\text {nd }}$ cycle & $1^{\text {st }}$ cycle & $2^{\text {nd }}$ cycle \\
\hline Arugula & $13.71 \mathrm{bB}$ & $20.04 \mathrm{aA}$ & $646.56 \mathrm{bB}$ & $986.70 \mathrm{aA}$ \\
\hline Arugula $+\operatorname{nira}(2 \mathrm{R}: 3 \mathrm{~N})$ & $21.13 \mathrm{aA}$ & $14.87 \mathrm{bB}$ & $1,015.47 \mathrm{aA}$ & $615.83 \mathrm{bB}$ \\
\hline Arugula $+\operatorname{nira}(2 \mathrm{R}: 2 \mathrm{~N})$ & $16.58 \mathrm{bA}$ & $15.33 \mathrm{bA}$ & $1,000.16 \mathrm{aA}$ & $646.95 \mathrm{bB}$ \\
\hline Arugula $+\operatorname{nira}(2 \mathrm{R}: 1 \mathrm{~N})$ & $20.92 \mathrm{aA}$ & $19.27 \mathrm{aA}$ & $944.82 \mathrm{aA}$ & $781.29 \mathrm{abA}$ \\
\hline CV1 (\%) & \multicolumn{2}{|c|}{11.40} & \multicolumn{2}{|c|}{22.59} \\
\hline CV2 (\%) & \multicolumn{2}{|c|}{10.70} & \multicolumn{2}{|c|}{14.57} \\
\hline
\end{tabular}
arrangements with nira and production cycle (winter and spring). Fortaleza, UFC, 2017.

$2 \mathrm{R}: 3 \mathrm{~N}=$ two rows of arugula alternated with three rows of nira; $2 \mathrm{R}: 2 \mathrm{~N}=$ two rows of arugula alternated with two rows of nira; $2 \mathrm{R}: 1 \mathrm{~N}=$ two rows of arugula alternating with one row of nira. Averages followed by the same lowercase letter in the column and uppercase in the line do not differ statistically among each other $(\mathrm{p} \leq 0.05)$ by Tukey test. 
Table 2. Marketable fresh mass (MFM), marketable dry mass (MDM) and plant height (PH) of arugula plants in relation to different cultivation arrangements with nira and production cycle (winter and spring). Fortaleza, UFC, 2017.

\begin{tabular}{lcclllr}
\hline \multirow{2}{*}{$\begin{array}{l}\text { Cultivation } \\
\text { system }\end{array}$} & \multicolumn{2}{c}{ MFM (g) } & & \multicolumn{2}{c}{ MDM (g) } \\
\cline { 2 - 3 } \cline { 6 - 7 } & $\mathbf{1}^{\text {st }}$ cycle & $\mathbf{2}^{\text {nd }}$ cycle & & $\mathbf{1}^{\text {st }}$ cycle & $\mathbf{2}^{\text {nd }}$ cycle \\
\hline Arugula & $40.36 \mathrm{bB}$ & $40.36 \mathrm{bB}$ & & $3.89 \mathrm{bB}$ & $20.23 \mathrm{aA}$ \\
Arugula + nira (2R:3N) & $73.94 \mathrm{aA}$ & $73.94 \mathrm{aA}$ & & $6.42 \mathrm{aA}$ & $6.10 \mathrm{cB}$ \\
Arugula + nira (2R:2N) & $66.64 \mathrm{aA}$ & $66.64 \mathrm{aA}$ & & $5.66 \mathrm{aB}$ & $6.97 \mathrm{cA}$ \\
Arugula + nira (2R:1N) & $73.64 \mathrm{aA}$ & $73.64 \mathrm{aA}$ & & $6.66 \mathrm{aB}$ & $14.97 \mathrm{bA}$ \\
\hline CV 1 (\%) & \multicolumn{2}{c}{20.93} & & \multicolumn{2}{c}{20.93} \\
CV 2 (\%) & \multicolumn{2}{c}{10.55} & & \multicolumn{2}{c}{10.55} \\
\hline
\end{tabular}

\begin{tabular}{ll}
\hline & PH $(\mathbf{c m})$ \\
\hline $1^{\circ}$ Cycle & $2.70 \mathrm{a}$ \\
$2^{\circ}$ Cycle & $2.36 \mathrm{~b}$ \\
\hline
\end{tabular}

$2 \mathrm{R}: 3 \mathrm{~N}=$ two rows of arugula alternated with three of nira; $2 \mathrm{R}: 2 \mathrm{~N}=$ two rows of arugula alternated with two of nira; $2 \mathrm{R}: 1 \mathrm{~N}=$ two rows of arugula alternated with one of nira. Averages followed by the same lowercase letter in the column and uppercase in the line do not differ statistically from each other, by the Tukey test $(\mathrm{p} \leq 0.05)$.

Table 3. Plant height (PH), average number of tillers per plant (NTPP), number of leaves (NL), marketable fresh mass (MFM), marketable dry mass (MDM) and productivity (PROD) of nira plants in different cultivation arrangements with arugula. Fortaleza, UFC, 2017.

\begin{tabular}{lcccccc}
\hline $\begin{array}{l}\text { Cultivation } \\
\text { system }\end{array}$ & $\begin{array}{c}\text { PH } \\
(\mathbf{c m})\end{array}$ & NTPP & NL & $\begin{array}{c}\text { MFM } \\
(\mathbf{g})\end{array}$ & $\begin{array}{c}\text { MDM } \\
(\mathbf{g})\end{array}$ & $\begin{array}{c}\text { PROD } \\
\left.\mathbf{( t ~ h a}^{-1}\right)\end{array}$ \\
\hline Nira & $35.50 \mathrm{a}$ & $4.67 \mathrm{a}$ & $33.40 \mathrm{a}$ & $45.37 \mathrm{a}$ & $5.83 \mathrm{~b}$ & $45.37 \mathrm{a}$ \\
Arugula + nira (2R:3N) & $35.41 \mathrm{a}$ & $4.55 \mathrm{a}$ & $33.47 \mathrm{a}$ & $41.80 \mathrm{a}$ & $6.28 \mathrm{~b}$ & $15.67 \mathrm{~b}$ \\
Arugula + nira (2R:2N) & $36.68 \mathrm{a}$ & $4.55 \mathrm{a}$ & $34.15 \mathrm{a}$ & $41.10 \mathrm{a}$ & $6.28 \mathrm{~b}$ & $11.74 \mathrm{~b}$ \\
Arugula + nira (2R:1N) & $36.52 \mathrm{a}$ & $5.42 \mathrm{a}$ & $36.55 \mathrm{a}$ & $49.75 \mathrm{a}$ & $8.51 \mathrm{a}$ & $8.29 \mathrm{~b}$ \\
\hline $\mathrm{CV} \mathrm{( \% )}$ & 6.83 & 17.05 & 14.32 & 21.57 & 12.28 & 37.16 \\
\hline
\end{tabular}

$2 \mathrm{R}: 3 \mathrm{~N}=$ two rows of arugula alternated with three of nira; $2 \mathrm{R}: 2 \mathrm{~N}=$ two rows of arugula alternated with two of nira; $2 \mathrm{R}: 1 \mathrm{~N}=$ two rows of arugula alternated with one of nira. Averages followed by the same letter in the columns do not differ statistically from each other, using Tukey test, $\mathrm{p} \leq 0.05$.

Table 4. Partial land use efficiency index (LUE), total land use efficiency index (Total LUE), relative contribution of arugula crop to LUE (RCC) and system productive index (SPI) of the intercropped crops of arugula and nira in different cultivation arrangements. Fortaleza, UFC, 2017.

\begin{tabular}{|c|c|c|c|c|c|}
\hline \multirow{2}{*}{ Cultivation system } & \multicolumn{2}{|c|}{ Parcial LUE } & \multirow{2}{*}{$\begin{array}{c}\text { RCC } \\
(\%)\end{array}$} & \multirow{2}{*}{$\begin{array}{l}\text { Total } \\
\text { LUE }\end{array}$} & \multirow{2}{*}{$\begin{array}{c}\text { SPI } \\
\left(t \text { ha }^{-1}\right)\end{array}$} \\
\hline & Arugula & Nira & & & \\
\hline Arugula & 1.00 & - & - & 1.00 & 30.32 \\
\hline Nira & - & 1.00 & - & 1.00 & 45.37 \\
\hline Arugula $+\operatorname{nira}(2 \mathrm{R}: 3 \mathrm{~N})$ & 0.51 & 0.35 & 59.43 & 0.85 & 25.82 \\
\hline Arugula $+\operatorname{nira}(2 \mathrm{R}: 2 \mathrm{~N})$ & 0.54 & 0.26 & 67.76 & 0.80 & 24.34 \\
\hline Arugula $+\operatorname{nira}(2 \mathrm{R}: 1 \mathrm{~N})$ & 0.98 & 0.18 & 84.27 & 1.16 & 35.24 \\
\hline
\end{tabular}

$2 \mathrm{R}: 3 \mathrm{~N}=$ two rows of arugula alternated with three of nira; $2 \mathrm{R}: 2 \mathrm{~N}=$ two rows of arugula alternated with two of nira; $2 \mathrm{R}: 1 \mathrm{~N}=$ two rows of arugula alternated with one of nira. cucumber caused greater restriction of solar radiation on lettuce (Rezende et al., 2010). Melo et al. (2015) evaluated the viability of Chinese cabbage/beet intercropping and noticed that in the intercropping with alternating row arrangement, interspecific competition was noticed, influencing negatively on the productivity of both species.

Arugula productivity was higher in $2 \mathrm{R}: 1 \mathrm{~N}$ arrangement in the first production cycle, whereas in the second cycle, aragula monocrop showed higher productivity (Figure 1).

The authors could verify that the lowest relative population density of nira in $2 \mathrm{R}: 1 \mathrm{~N}$ arrangement contributed to a better performance, being similar behavior observed in nira monocrop. This fact can be explained due to a greater interspecific competition for spaces in other intercropping arrangements observed on account of a greater number of nira plants. In the second cycle, the highest productivity of arugula monocrop was probably due to a greater development of nira plants, which caused greater shading on the arugula, in addition to a lower incidence of rainfall, which caused less damage to plants. Similarly, Camili et al. (2013), working with lettuce/taro intercropping, observed that rapid growth of taro and, consequently, rapid formation of leaf area interfered in lettuce productivity in the second cycle of intercropping.

For nira, cultivation arrangements only influenced on the marketable dry mass (MDM) and productivity $(\mathrm{p} \leq 0.05)$ (Table 3). For nira MDM, 2R:1N intercropping showed the greatest average. In other treatments, population pressure of the highest densities of nira may have caused a more intense competition for environmental resources such as solar radiation, resulting in less accumulation of dry mass in the shoot of nira. According to Taiz et al. (2017), a decrease in light intensity causes a reduction in photosynthetic activity, with a concomitant decrease in the production of photoassimilates by the plant, which reduces the accumulation of mass in the plants.

Productivity of nira was higher under monoculture, considering the highest relative population density by area. In 
average, single cultivation showed yield $381.2 \%$ above the intercropped crops.

For agronomic performance indexes of arugula/nira intercropping systems, we observed greater efficiency in land use in the $2 \mathrm{R}: 1 \mathrm{~N}$ intercropping, which showed efficiency $16 \%$ above the monocrop of arugula and nira (Table 4). Therefore, we can infer that the effects of cooperation or compensation between intercropped crops contributed to the advantages of the intercropping (Barros Júnior et al., 2011).

Evaluating the efficiency of Aliaceae and Brassicaceae families intercropping, Hendges et al. (2017) observed LUE ratio of 1.33 for green onion/collard intercropping, showing greater intercropping efficiency. In other intercropping systems, such as arugula and beet (Beta vulgaris var. conditiva) (Grangeiro et al., 2007); arugula and chicory (Cichorium intybus) (Cecilio Filho et al., 2008); arugula, lettuce and radish (Zanol et al., 2007), LUE was higher than 1.00 , showing better production levels in relation to single cultivations.

Land use efficiency of $2 \mathrm{R}: 1 \mathrm{~N}$ intercropping was observed mainly to a high productive performance of arugula, which contributed significantly for LUE, with approximately $84.3 \%$. This fact leads to greater productive stability of the system, considering the system productivity index, which was $16.55 \%$ higher than the single arugula crop. According to Heredia Zárate et al. (2007), the increase in production per unit area is one of the most important reasons for cultivating two or more associated crops as it allows better use of land and other available resources, resulting in greater economic yield. However, to make it possible, the arrangement of plants in the growing area should be done in the most favorable way for both crops.

The intercropping system of two rows of arugula cultivation alternated with one row of nira made it possible to obtain productivity similar to single arugula cultivation, with greater agronomic efficiency in the use of productive resources when compared to the other arrangements, though.

\section{ACKNOWLEDGEMENTS}

To the National Council for Scientific and Technological Development (CNPq) for giving scholarships to HS Lemos Neto (PDJ- Proc. 154458/2018-0); MA Guimarães (PQ- Proc. 306653/2019-2); BP Lima Neto (GM); CS Viana (GD) and JS Rabelo (GD).

\section{REFERENCES}

ALVARES, CA; STAPE, JL; SENTELHAS, PC; GONÇALVES, JLM; SPAROVEK, G. 2014 Köppen's climate classification map for Brazil. Meteorologische Zeitschrift 22: 711-728.

BARROS JÚNIOR, AP; CECÍLIO FILHO, AB; REZENDE, BLA; PÔRTO, DRQ; PRADO, RM. 2011. Nitrogen fertilization on intercropping of lettuce and rocket. Horticultura Brasileira 29: 398-403.

CAMILI, EC; AZEVEDO, CCBV; BOCUTI, ED; SILVÉRIO, JM; BARROS, KC; SILVA, ARB; SEABRA JÚNIOR, S. 2013. Cultivo consorciado de alface sob diferentes arranjos espaciais e manejo do dossel de taioba. Revista Agrarian 6: 110-120.

CECILIO FILHO, AB; COSTA, CC; REZENDE, BL; LEEUWEN, RV. 2008. Viabilidade produtiva e econômica do consórcio entre chicória e rúcula em função da época de plantio. Horticultura Brasileira 26: 316-320.

DAMASCENO, ASV; MASSAROTO, JA; NASCIMENTO JUNIOR, AP; MUNHOZ, EM. 2016. Avaliação da produção de alface e rabanete em consórcio. Ciências Agroambientais 14: 76-81.

FERREIRA, DF. 2011. Sisvar: A computer statistical analysis system. Ciência e Agrotecnologia 35: 1039-1042.

GRANGEIRO, LC; BEZERRA NETO, F; NEGREIROS, MZ; CECÍLIO FILHO, AB; CALDAS, AVC; COSTA, NL. 2007. Produtividade da beterraba e rúcula em função da época de plantio em monocultivo e consórcio. Horticultura Brasileira 25 . 577-581.

GUIMARÃES, MA; OLIVEIRA, AB; DOVALE, JC. 2016. Manutenção de Hortas. Viçosa: Editora UFV, 156p.

HENDGES, ARAA; GUIMARÃES, MA; LEMOS NETO, HS; MESQUITA, RO. 2017. Physiological performance and competitive ability in kale (Brassica oleracea var. acephala 'Manteiga da Georgia') intercropped with important aromatic species and herbs. Australian Journal and Crop Science 11: 1181-1187.

HEREDIA ZÁRATE, NA; VIEIRA, MC; GIULIANI, AR; HELMICH, M; PONTIM, BCA; PEZZONI FILHO, JC. 2007. Produção e renda de taro Macaquinho, solteiro e consorciado com alface 'Salad Bowl', em solo com cobertura de cama-de-frango semidecomposta. Semina: Ciências Agrárias 28: 563-570.
LIMA, JSS; CHAVES, AP; BEZERRA NETO, F; SANTOS, EC; OLIVEIRA, FS. 2013. Produtividade da cenoura, coentro e rúcula em função de densidades populacionais. Revista Verde 8: 110-116.

LIRA, LLB; EDILSON, FPA. 2013. Sustentabilidade como ferramenta estratégica empresarial. Revista de Administração de UFSM 6: 195-210.

MELO, FS; SANTI, A; DALACORT, R; ROCGA, RP; SANTOS, ES; JUNIOR, CAF. 2015. Viabilidade do consórcio entre beterraba e couve-chinesa sob diferentes dias de transplante Acta Iguazu 4: 78-90.

NUNES, CJS; SOUZA, ML; FERREIRA, RLF. 2013. Qualidade e pós-colheita da rúcula orgânica armazenada sob refrigeração. Enciclopédia Biosfera, 9: 2231-2240.

ODO, PE. 1991. Evaluation of short and tall sorghum varieties in mixtures with cowpea in the Sudan savanna of Nigeria: land equivalent ratio, grain yield and system productivity index. Experimental Agriculture 27: 435-441.

OLIVEIRA, LAA; BEZERRA NETO, F; SILVA, ML; OLIVEIRA, OFN; LIMA, JSS; BARROS JUNIOR, AP. 2015. Viabilidade agronômica de policultivos de rúcula/cenoura/ alface sob quantidades de flor-de-seda e densidades populacionais. Revista Caatinga 28: 116-126.

PORTO, VCN. 2008. Bicultivo de alface e rúcula consorciadas com cenoura em faixas. 2008. UFERSA. 97p. (Ph.D. Thesis)

REZENDE, BLA; CECILIO FILHO, AB; PÔRTO, DRQ; BARROS JUNIOR, AP; SILVA, GS; BARBOSA, JC; LUIS FELTRIM, A. 2010. Consórcio de alface crespa e pepino em função da população do pepino e época de cultivo. Interciencia 35: 374-379.

SILVA, AO; SILVA, DJR; SOARES, TM; SILVA, EFF; SANTOS, NA; ROLIM, MM. 2011. Produção de rúcula em sistema hidropônico NFT utilizando água salina do Semiárido - PE e rejeito de dessalinizador. Revista Brasileira de Ciências Agrárias 6: 147-155.

SOUZA, JP; MACEDO, MAS. 2007. Análise de viabilidade agroeconômica de sistemas orgânicos de produção consorciada. $A B C$ istos Associação Brasileira de Custos 2: 57-78.

SUGASTI, JB; JUNQUEIRA, AMR; SABOYA, PA. 2013. Consórcio de rabanete, alface e quiabo e seu efeito sobre as características agronômicas das culturas, produção e índice de equivalência de área. Revista Brasileira de Agroecologia 8: 214-225.

TAIZ, L; ZEIGER, E; MØLLER, IM; MURPHY, A. 2017. Fisiologia e Desenvolvimento Vegetal. Porto Alegre: Artmed, $888 \mathrm{p}$.

WILLEY, RW. 1979. Intercropping: its importance and research needs. Part 1. Competition and yield advantages. Field Crop Abstracts 32: $1-10$.

ZANINE, AM; SANTOS, EM. 2004. Competição entre espécies de plantas - uma revisão. Revista FZVA 11: 10-30.

ZANOL, SV; FARIAS, RM; MARTINS, CR; ROSSOROLLA, MD; PIVOTO, HC. 2007. Cultivo de hortaliças companheiras em sistema agroecológico, período primavera-verão na situação de Uruguaiana-RS. Revista Brasileira de Agroecologia 2: 1549-1552. 